\title{
Anxiety and knowledge of patients before being subjected to orthognathic surgery
}

\author{
Ansiedade e conhecimento de pacientes submetidos a cirurgia ortognática no pré-operatório \\ Ansiedad y conocimiento de pacientes sometidos a cirugía ortognática en el preoperatorio
}

\section{Pâmella Simões Barel', Cristina Silva Sousa', Vanessa de Brito Poveda', Ruth Natalia Teresa Turrini'}

' Universidade de São Paulo, School of Nursing. São Paulo, Brazil.

How to cite this article:

Barel PS, Sousa CS, Poveda VB, Turrini RNT. Anxiety and knowledge of patients before being subjected to orthognathic surgery. Rev Bras Enferm [Internet]. 2018;71(Suppl 5):2081-6. [Thematic Issue: Mental health]

DOI: http://dx.doi.org/10.1590/0034-7167-2017-0520

Submission: 08-04-2017

Approval: 11-01-2017

\section{ABSTRACT}

Objective: to verify the correlation between anxiety level and degree of knowledge in patients before they are subjected to orthognathic surgery. Method: Descriptive cross-sectional study with 40 patients in the preoperative period before orthognathic surgery of a private clinic in the city of São Paulo. Results: IDATE-trait anxiety levels feature prevalence of medium-level anxiety with $72.5 \%(n=29)$, followed by low-level anxiety with $72.5 \%(n=29)$ and high-level level anxiety with $10 \%(n=4)$. In the preoperative period, transitory IDATE-state anxiety levels feature medium-level anxiety with $65 \%(n=26)$, followed by high-level anxiety with $22.5 \%(n=9)$ and low-level anxiety with $10 \%(n=4)$. Pearson's correlation coefficient resulted in negative $r(-0.2)$ for anxiety-trait $(p$ 0.197) and in negative $r(-0.1)$ for anxiety-state ( $p$ 0.417). Conclusion: The data shows a weak correlation in which greater knowledge about the surgical procedure reduces levels of anxiety that may be related to the absence of appropriate guidance about the surgical procedure.

Descriptors: Orthognathic Surgery; Perioperative Nursing; Anxiety; Patient Education as Topic; Patient Education Handout.

\section{RESUMO}

Objetivo: verificar a correlação entre nível de ansiedade e grau de conhecimento em pacientes no pré-operatório de cirurgia ortognática. Método: Estudo transversal descritivo com 40 pacientes em pré-operatório de cirurgia ortognática de uma clínica privada no município de São Paulo. Resultados: Os níveis de ansiedade IDATE-traço apresentam uma prevalência de ansiedade de médio grau com $72,5 \%(n=29)$, seguido de baixo grau $17,5 \%(n=7)$ e alto grau $10 \%(n=4)$. E apresentavam no momento pré-operatório níveis de ansiedade transitório IDATE-estado de médio grau com $65 \%(n=26)$, seguido de alto grau $22,5 \%(n=9)$ e baixo grau $10 \%(n=4)$. A correlação de Pearson resultou em $r$ negativo $(-0,2)$, para ansiedade-traço ( $p$ 0.197) e ansiedade-estado valor $r$ negativo $(-0,1)$ ( $p$ 0.417). Conclusão: Os dados demonstram uma correlação fraca na qual maior conhecimento sobre o procedimento cirúrgico reduza os níveis de ansiedade que pode estar relacionado ausência de orientações adequadas sobre o procedimento cirúrgico.

Descritores: Cirurgia Ortognática; Enfermagem Perioperatória; Ansiedade; Educação de Pacientes como Assunto; Prospecto para Educação de Pacientes.

\section{RESUMEN}

Objetivo: verificar la correlación entre nivel de ansiedad y grado de conocimiento en pacientes en el preoperatorio de cirugía ortognática. Método: Estudio transversal descriptivo con 40 pacientes en preoperatorio de cirugía ortognática de una clínica privada en la ciudad de São Paulo. Resultados: Los niveles de ansiedad IDATE-trazo presentan una prevalencia de ansiedad de medio grado con el $72,5 \%(n=29)$, seguido de bajo grado, con el $17,5 \%(n=7)$, y alto grado con el $10 \%(n=4)$. En el momento preoperatorio, los niveles de ansiedad transitoria IDATE-estado de medio grado con el $65 \%(n=26)$, seguido de alto grado, con el 22,5\% $(n=9)$, y bajo grado, con el $10 \%(n=4)$. La correlación de Pearson resultó en $r$ negativo $(-0,2)$, para ansiedad-trazo ( p 0.197) y ansiedad-estado valor $r$ negativo $(-0,1)$ ( $p$ 0.417). Conclusión: Los datos demuestran una correlación débil en la 
que mayor conocimiento sobre el procedimiento quirúrgico reduzca los niveles de ansiedad, lo que puede estar relacionado ausencia de orientaciones adecuadas sobre el procedimiento quirúrgico.

Descriptores: Cirugía Ortognática; Enfermería Perioperatoria; Ansiedad; Educación del Paciente como Asunto; Folleto Informativo para Pacientes.

\section{CORRESPONDING AUTHOR Cristina Silva Sousa E-mail: crissousa@usp.br}

\section{INTRODUCTION}

Preparing for an invasive surgical procedure is an experience that typically generates anxiety in patients. The waiting period before the operation may contribute to triggering stress because it promotes concern with the surgical procedure. The patient experiences the feeling of fear of something going wrong during the procedure, and anxiety in relation to the outcome of the surgery ${ }^{(1)}$.

In this way, anxiety is considered a normal part of the preoperative experience ${ }^{(2)}$. It being ordinary, however, does not mean that it should be ignored. Part of the role of nurses in the perioperative context is administering the anxiety of patients to promote a positive surgical outcome and satisfaction with the surgical experience ${ }^{(1)}$.

Anxiety triggers the response to stress, stimulating the release of epinephrine and norepinephrine, which increases blood pressure and heart rate, thus elevating the cardiac output ${ }^{(3)}$. It can have psychological components and inhibit learning, concentration and routine tasks $\mathrm{s}^{(1,4)}$. Maintaining a minimum anxiety level is important in the preoperative period, because if patients are anxious, they may be unable to retain important home care instructions ${ }^{(1)}$.

The causes that may trigger anxiety in patients during the preoperative period may include: waiting to be taken to surgery, experiencing an unknown environment, loss of control, being separated from friends and/or family, results of unwanted diagnoses, loss of identity while in the hospital, uncertainty about postoperative recovery and a feeling that the events are out of their control ${ }^{(5)}$.

The patients of this research were subjected to orthognathic surgery, which is the correction of dentofacial deformities, aiming at the functional, anatomic and aesthetic improvement of the patient's face. The treatment requires a combination of preoperative orthodontics, orthognathic surgery and postoperative orthodontics, having as goals facial and dental harmony, functional occlusion and stability of the procedure ${ }^{(6)}$.

This surgical procedure has risks, possible complications and requires a long treatment time, interfering with social and psychological aspects of the patient. It seeks improvements in the abilities of mastication, swallowing, breathing and speech and, in many cases, also in the facial aesthetics ${ }^{(7)}$.

\section{OBJECTIVE}

To verify the correlation between anxiety level and degree of knowledge in patients before they are subjected to orthognathic surgery.

\section{METHOD}

\section{Ethical aspects}

The data from this study are part of a thematic project which aims to evaluate the effectiveness of an educational material through a randomized clinical trial, approved by the Ethics
Committee of the School of Nursing at the University of São Paulo (CEP/EEUSP), and registered in the National Institutes of Health (NHS) - Clinical Trial with handle NCT01803204.

\section{Design, study site and period}

Descriptive cross-sectional study conducted with patients in the preoperative period before orthognathic surgery of a private oral and maxillofacial surgery clinic in the city of São Paulo, during the period proposed for data collection (August 2013 to August 2014).

\section{Population or sample; inclusion and exclusion criteria}

Convenience sampling was carried out based on the condition of a small number of surgeries performed per month (two to three) in a single private oral and maxillofacial surgery clinic. Forty patients in the preoperative period before orthognathic surgery were established. The inclusion criteria adopted were: being over eighteen years old, being subjected to orthognathic surgery (surgical technique: bilateral osteotomy of the sagittal maxillary branch, osteotomy of the vertical maxillary branch, Lefort I osteotomy, combined osteotomy, with application or not of mentoplasty and maxillary disjunction) by the same surgical team. Patients subjected to reoperation of orthognathic surgery and patients with orofacial cleft were excluded.

\section{Study protocol}

For data collection, patients who met the inclusion criteria were approached personally by the researcher in the clinic's office, as they prepared for the surgical procedure, during the pre-operative consultation with the surgeon, and were invited to participate in the research. If they accepted, after filling the informed consent form, they were asked to fill the two collection instruments and then proceeded to the block randomization stage, which constitutes the thematic project which this research is part of.

During this period, the patients did not receive any specific guidance on the surgical procedure, so their prior knowledge and anxiety level could be assessed.

The instruments were composed by the state-trait anxiety inventory - IDATE (developed by Spielberger in 1970), which assesses two dimensions of anxiety, the transitory state and the relatively stable state of the patient's personality. This scale consists of twenty claims and, for each claim, the patient must check one of the four alternatives, indicating how they feel: absolutely not; a little; a lot; very much (in the IDATE-state scale); almost never; sometimes; often; almost always (in the IDATE-trait scale) ${ }^{(8)}$. The total score is characterized by low degree of anxiety (20-30 points), medium degree of anxiety (31-49) and high degree of anxiety (50 or more $)^{(9)}$.

The test of knowledge about the operation, which consisted of ten multiple-choice questions about the surgery and postoperative care, with a maximum score of ten, was developed by the researcher and validated by two professional perioperative nurses 
and applied to the patient preoperatively and postoperatively. This instrument was subjected to a pre-test in orthognathic surgery patients, and after psychometric analysis by Rasch's method, it was redesigned for application in the study population ${ }^{(10)}$.

\section{Analysis of the results and statistics}

The data collected were entered into a Microsoft Excel worksheet, and then analyzed by the Statistical Package for the Social Sciences (SPSS 20.0), whereas for the descriptive analyses, absolute numbers, percentage, mean and standard deviation were used; for correlation, Pearson's test was used, after the sample's normality had been verified with the Kolmogorov-Smirnov test.

\section{RESULTS}

The average age of the participants was $27 \pm 7.5$ years old; $100 \%$ of the sample denies previous clinical history such as smoking, diabetes and obesity. The other sociodemographic characteristics analyzed are presented in Table 1.

In relation to the knowledge test applied, the minimum value of correct answers was one point and the maximum value was nine points, the average test score having been $4.2+2$ points. The values of correct answers per question are shown in Table 2.

The samples were subjected to the Kolmogorov-Smirnov normality test ( $p$ 0.469). Pearson's correlation coefficient resulted in negative $r(-0.2)$, showing a weak correlation in which increase in knowledge reduces anxiety-trait ( $p$ 0.197) (Figure 1). In relation to anxiety-state, Pearson's correlation also resulted in negative $r(-0.1)$, showing a very weak correlation in which increase in knowledge reduces anxiety-state (p 0417) (Figure 2).

Table 1 - Sociodemographic characteristics of patients in the preoperative period before orthognathic surgery, 2014

\begin{tabular}{lcc}
\hline \multicolumn{1}{c}{ Variables } & $\mathbf{n}$ & $\mathbf{\%}$ \\
\hline Age group & & \\
15-20 years old & 9 & 22.5 \\
21-25 years old & 9 & 22.5 \\
25-30 years old & 8 & 20.0 \\
31-35 years old & 10 & 25.0 \\
36-40 years old & 3 & 7.5 \\
>40 years old & 1 & 2.5 \\
& & \\
Sex & 20 & 50.0 \\
Female & 20 & 50.0 \\
Marital status & & \\
Single & 26 & 65.0 \\
Married & 14 & 35.0 \\
Educational level & & \\
Elementary school & 2 & 5.0 \\
High school & 15 & 37.5 \\
Some high school & 8 & 20.0 \\
Higher education degree & 11 & 27.5 \\
Some higher education & 04 & 10.0 \\
\hline & \multicolumn{2}{c}{} \\
\hline
\end{tabular}

Table 2 - Number of correct answers in the knowledge test, 2014

\begin{tabular}{lcc}
\hline Questions & $\mathbf{n}$ & $\%$ \\
\hline $\begin{array}{l}\text { 01. How is the surgery } \\
\text { 02. After surgery is it possible }\end{array}$ & 32 & 80.0 \\
$\begin{array}{l}\text { 03. In case of small bleeding in the mouth after } \\
\quad \text { surgery should I }\end{array}$ & 6 & 72.5 \\
04. To help the recovery from the surgery and of my & 13 & 32.5 \\
$\quad$ face's mobility can I & 9 & 22.5 \\
05. Will my face stay swollen for & 7 & 17.5 \\
06. In relation to lip care should I & 16 & 40.0 \\
07. In relation to brushing my teeth should I & 22 & 55.0 \\
08. In relation to food after surgery should I & 26 & 65.0 \\
09. In relation to bathing after surgery should I & 10 & 25.0 \\
10. In relation to my activities, soon after surgery should I
\end{tabular}

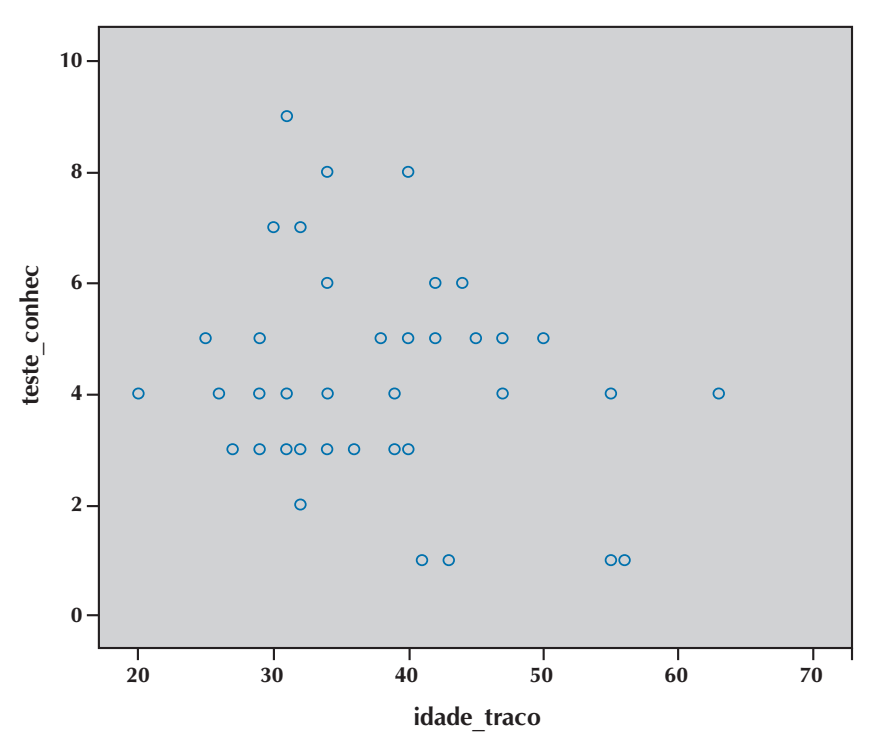

Figure 1 - Measure of dispersion of the correlation between IDATE-trait and the knowledge test, 2014

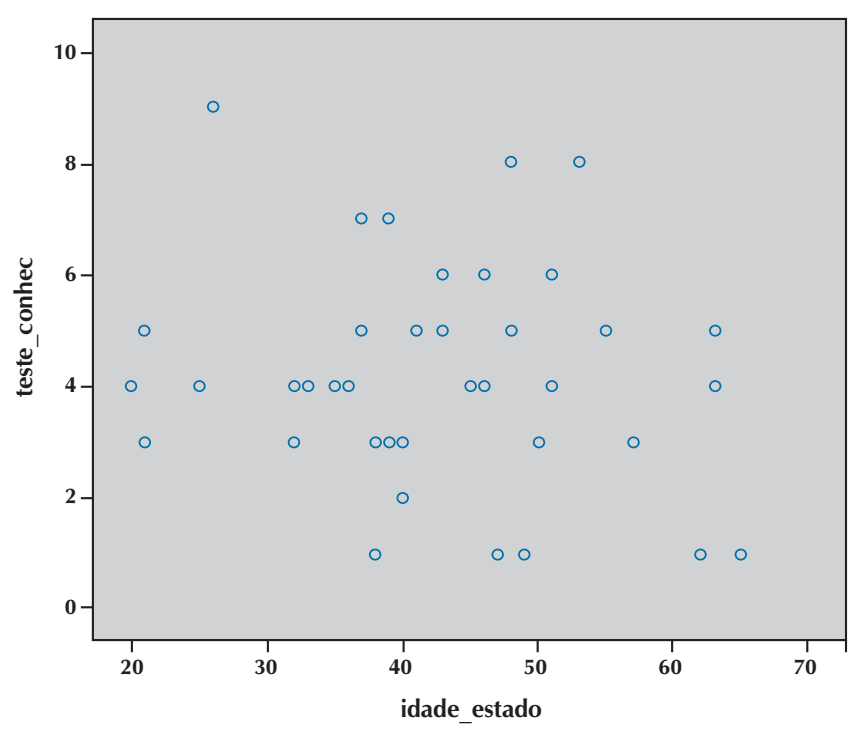

Figure 2 - Measure of dispersion of the correlation between IDATE-state and the knowledge test, 2014 


\section{DISCUSSION}

Gender rate was balanced in this study, but in another study there is predominance of women in the sample population ${ }^{(11)}$. The average age is similar to other studies with evaluation of preoperative anxiety before orthognathic surgery ${ }^{(11-12)}$. Single marital status predominated, similarly to another study ${ }^{(13)}$. In relation to education and literacy, the patients of this research did not have low literacy, as they had on average nine years of study. This profile is similar to that found in the literature ${ }^{(13)}$.

The questions which indicated lower knowledge level of the patients about postoperative care/orthognathic surgery $(<50 \%$ correct answers) were related to oral bleeding, actions to aid in recovery, time of the edema, lip care, oral hygiene and activities during the postoperative period.

In medical or dental clinics, it is common that only professionals who make up the surgical team are involved in preparing the patient for the surgery to be performed, addressing only the surgical technique to be undertaken and the expected conduction of the treatment. However, in this preoperative moment, patients are undergoing pre-operative tests, preparing for putting their daily activities on hold and involved in the moment of finally correcting their dentofacial deformity, which can hinder the assimilation of verbal information provided by the surgical team.

Studies conducted in Brazi ${ }^{(14-15)}$ on the perception/knowledge of patients after orthognathic surgery report the patients' difficulty to carry out oral hygiene and feed themselves properly, which can predispose the presence of food residue in the oral cavity, halitosis, gingivitis and infection. It is assumed that patients become afraid to move their lips and cheeks and show or touch the suture.

Based on the patient's prior knowledge, and on a prospect of correct answers above $70 \%$, the results of this research showed that patients with dentofacial deformity only have knowledge about the surgery and sensations in the postoperative period (changes to the bite, sensitivity). This fact is due to internet access and the generalized information which these patients have access to. In a study on the evaluation of information that patients subjected to orthognathic surgery exchange with peers outside of the clinical setting, which assessed 1912 posts on forums about the subject, it was observed that patients seek information on the internet to complement those relating to their treatment, as well as support and similarities with the treatment of their peers ${ }^{(16)}$

However, this generalized information does not allow the patient to acquire enough knowledge to carry out their domiciliary care in the postoperative period. A study in the United Kingdom ${ }^{(17)}$ assessed the quality of the information on websites about orthognathic surgery. Of the 25 sites evaluated, the maximum score was 64-80 points, below the minimum score of 80 for information to be considered excellent. For this evaluation, a validated instrument called DISCERN ${ }^{1}$ was used, which consists of 16 questions about the quality and reliability of information about health problems disclosed to consumers.
A study in Jordan ${ }^{(18)}$ on the perception of patients subjected to orthognathic surgery states that they believed that the preoperative information was adequate, but suggested the use of additional materials, including leaflets or videos, to assimilate the data received. In this study, meeting the surgical center's nurse before surgery was also suggested.

The best way to teach adults is using complementary educational technologies as reinforcement of verbal information. In this way, the patient can refer to information about the surgical procedure after the other activities related to preparation have already been concluded.

Booklets, software and other media are the instruments which are most often applied by nurses. A booklet is a printed educational material that assists the patient with information about health, satisfaction and adherence to treatment, developing the ability of autonomy in health care ${ }^{(19)}$. Websites, software and videos are instruments that enable the acquisition of knowledge through interaction, in addition to stimulating reflection and learning ${ }^{(20)}$. Thus, the choice of strategy and its application must be adapted to the needs of the patient, which increases the chance of modification of erroneous beliefs and behaviors, as well as of addition of new notions and ideas.

Values for the medium and high degree of anxiety in patients with dentofacial deformity during the preoperative phase were similar to other studies ${ }^{(11,21)}$. An investigation carried out in Italy on the level of dentofacial deformity before surgery showed that patients with greater dentofacial deformity had higher levels of introversion, anxiety-trait, dependency, unsociability, leadership and neuroticism ${ }^{(22)}$.

Another study reinforces the social aspect of dentofacial deformities in patients who sought the surgical procedure; they were asked whether their affective relationships were impacted by their facial aesthetics: $45 \%$ of patients said yes, and most patients were male. When asked if, because of their facial symmetry, they felt different from other people, $60 \%$ said yes ${ }^{(13)}$.

\section{Study limitations}

Among the limitations of this study are a relatively small sample of a single private clinic in the city of São Paulo, and the fact that the patients of this study had some information about the surgical procedure that was possibly not acquired properly. The weak correlation can be explained by the sources of the patients' knowledge having possibly been inadequate. Further studies are recommended with appropriate educational strategies to affirm the results found.

\section{Contributions to the field of Nursing}

Preoperative anxiety is a reality often experienced in the perioperative period in patients with little or a lot of knowledge about the surgical procedure. Despite the limitations of this study, a greater awareness on the part of patients in relation to the surgical procedure failed to reduce their anxiety while facing the perioperative process. Thus, understanding and dealing with this feeling of patients, through educational interventions,

1 Available from: www.discern.org.uk/discern_instrument.php. 
assistance and family support can help the surgical patient face this process.

\section{CONCLUSION}

The data from this study show that patients with dentofacial deformity have poor knowledge about orthognathic surgery and there is weak correlation in which greater knowledge about the surgical procedure reduces the levels of preoperative anxietytrait, and very weak correlation with respect to anxiety-state.
The need to educate the patients during the preoperative period in relation to the surgical procedure and postoperative care are noted, in addition to mediating actions that help control anxiety to improve the self-care performed by these patients.

\section{FUNDING}

National Science and Technology Council (CNPq; Scientific Initiation scholarship).

\section{REFERENCES}

1. Brand LR, Munroe DJ, Gavin J. The effect of hand massage on preoperative anxiety in ambulatory surgery patients. AORN J[Internet]. 2013[cited 2017 Jun 12];97(6):708-17. Available from: http://www.sciencedirect.com/science/article/pii/S0001209213003827

2. Bailey L. Strategies for decreasing patient anxiety in the perioperative setting. AORN J[Internet]. 2010[cited 2017 Jun 10];92(4):44557. Available from: http://www.aornjournal.org/article/S0001-2092(10)00785-4/fulltext

3. Carroll JK, Cullinan E, Clarke L, Davis NF. The role of anxiolytic premedication in reducing preoperative anxiety. Br J Nurs[Internet]. 2012[cited 2017 Jun 10];21(8):479-83. Available from: http://www.magonlinelibrary.com/doi/abs/10.12968/bjon.2012.21.8.479

4. Akinsulore A, Owjuyigbe AM, Faponle AF, Fatoye FO. Assessment of preoperative and postoperative anxiety among elective major surgery patients in a tertiary hospital in Nigeria. Middle East J Anaesthesiol[Internet]. 2015[cited 2017 Jul 26];23(2):235-40. Available from: http://www.meja.aub.edu.lb/downloads/23_2/235.pdf

5. Davis-Evans C. Alleviating anxiety and preventing panic attacks in the surgical patients. AORN J[Internet]. 2013 [cited 2017 Jul 26];97(3):354-64. Available from: http://www.aornjournal.org/article/S0001-2092(12)01352-X/pdf

6. Guimarães Filho R, Oliveira Jr EC, Mesquita Gomes TR, Souza TDA. Quality of life in patients who undergo orthognathic surgery: oral health and self-esteem. Psicol Ciênc Prof[Internet]. 2014[cited 2017 Jun 10];34(1):242-51. Available from: http://www.scielo. $\mathrm{br} / \mathrm{pdf} / \mathrm{pcp} / \mathrm{v} 34 \mathrm{n} 1 / \mathrm{v} 34 \mathrm{n} 1 \mathrm{a} 17 . \mathrm{pdf}$

7. Sousa CS, Turrini RN. Creating and validating educational material for patients undergoing orthognathic surgery. Asian Nurs Res[Internet] 2012[cited 2017 Jun 12];6(4):166-72. Available from: http://www.sciencedirect.com/science/article/pii/S1976131712000680

8. Julian LJ. Measures of anxiety: State-Trait Anxiety Inventory-STAI, Beck Anxiety Inventory-BAI, and Hospital Anxiety and Depression Scale-Anxiety-HADS-A. Arthritis Care Res[Internet]. 2011[cited 2017 Jun 10];63(S11):S467-72. Available from: http://onlinelibrary. wiley.com/doi/10.1002/acr.20561/full

9. Cevada T, Cerqueira LS, Moraes HS, Santos TM, Pompeu FAMS, Deslandes AC. Relationship between sport, resilience, quality of life, and anxiety. Rev Psiq Clin[Internet]. 2012[cited 2017 Jun 10];39(3):85-9. Available from: http://www.scielo.br/pdf/rpc/v39n3/ a03v39n3.pdf

10. Sousa CS, Turrini RNT, Poveda VB. Educational intervention in patients undergoing orthognathic surgery: pilot study. J Nurs Educ Pract[Internet]. 2015[cited 2017 Jun 15];5(5):126-34. Available from: http://www.sciedu.ca/journal/index.php/jnep/article/view/6236

11. Al-Bitar ZB, Al-Ahmad HT. Anxiety and post-traumatic stress symptoms in orthognathic surgery patients. Eur J Orthod[Internet]. 2017 [cited 2017 Jun 16];39(1):92-7. Available from: https://academic.oup.com/ejo/article/39/1/92/2629538/Anxiety-and-post-traumatic-stress-symptoms-in

12. Brunault $P$, Battini J, Potard C, Jonas C, Zagala-Bouquillon B, Chabut A, et al. Orthognathic surgery improves quality of life and depression, but not anxiety, and patients with higher preoperative depression scores improve less. Int J Oral Maxillofac Surg[Internet]. 2016[cited 2017 Jun 12];45:26-34. Available from: http://www.sciencedirect.com/science/article/pii/S0901502715012035

13. Abitante C, Schneider LE, Vargas IA, Bridi AO, Crusius KC, Krause RGS. Aesthetic motivation quantitative analysis of ULBRA's orthognathic surgery patient. Rev Ciênc Méd Biol[Internet]. 2011[cited 2017 Jun 10];9(3):185-8. Available from: https://portalseer. ufba.br/index.php/cmbio/article/view/5157/3723

14. Santos MR, Sousa CS, Turrini RN. Perception of orthognathic surgery patients on postoperative care. Rev Esc Enferm USP[Internet]. 2012[cited 2017 Jun 10];46(Spe):78-85. Available from: http://www.scielo.br/pdf/reeusp/v46nspe/12.pdf

15. Barros BR, Sousa CS, Turrini RNT. Knowledge of Internet-using patients about the perioperative period of orthognathic surgery. J Nurs Educ Pract[Internet]. 2013[cited 2017 Jun 12];3(12):93-102. Available from: http://www.sciedu.ca/journal/index.php/jnep/ article/view/2336

16. Bhamrah G, Ahmad S, NiMhurchadha S. Internet discussion forums, an information and support resource for orthognathic patients. Am J Orthod Dentofacial Orthop[Internet]. 2015[cited 2017 Jun 10];147(1):89-96. Available from: http://www.sciencedirect.com/ science/article/pii/S0889540614008622 
17. Aldairy T, Laverick S, Mclntyre GT. Orthognathic surgery: is patient information on the Internet valid? Eur J Orthod[Internet]. 2012 [cited 2017 Jun 10];34(4):466-9.Available from: https://academic.oup.com/ejo/article/34/4/466/491781/Orthognathic-surgery-is-patient-information-on-the

18. Ghannam SA, Malkawi ZA, Sawair FA, Baqain ZH. Perception of outcome after orthognathic surgery at Jordan University Hospital. Jordan Med J[Internet]. 2010[cited 2017 Jun 10];42(4):1-8. Available from: https://journals.ju.edu.jo/JMJ/article/view/959

19. Oliveira SC, Oliveira Lopes MV, Fernandes AFC. Development and validation of an educational booklet for healthy eating during pregnancy. Rev Latino-Am Enfermagem[Internet]. 2014[cited 2017 Oct 25];22:611-20. Available from: http://www.scielo.br/pdf/ rlae/v22n4/pt_0104-1169-rlae-22-04-00611.pdf

20. Fonseca LMM, Leite AM, Mello DF, Silva MAI, Lima RAG, Scochi CGS. Educational technology in health: contributions for pediatric and neonatal nursing. Esc Anna Nery Rev Enferm[Internet]. 2011 [cited 2017 Oct 25];15:190-6. Available from: http://www.scielo. br/pdf/ean/v15n1/27.pdf

21. Magro-Filho O, Goiato MC, Oliveira DTN, Martins LP, Salazar M, Medeiros RO, et al. Evaluation of patients' satisfaction after class III orthognathic surgery. J Clin Diagn Res[Internet]. 2015[cited 2017 Jun 12];9(10):ZC23-ZC27. Available from: https://www.ncbi. nlm.nih.gov/pmc/articles/PMC4625329/

22. Kovalenko A, Slabkovskaya A, Drobysheva N, Persin L, Drobyshev A, Maddalone M. The association between the psychological status and the severity of facial deformity in orthognathic patients. Angle Orthod[Internet]. 2011 [cited 2017 Jun 12];82(3):396-402. Available from: http://www.angle.org/doi/pdf/10.2319/060211-363.1 